\title{
Investigating a new wealth tax in South Africa: Lessons from international experience
}

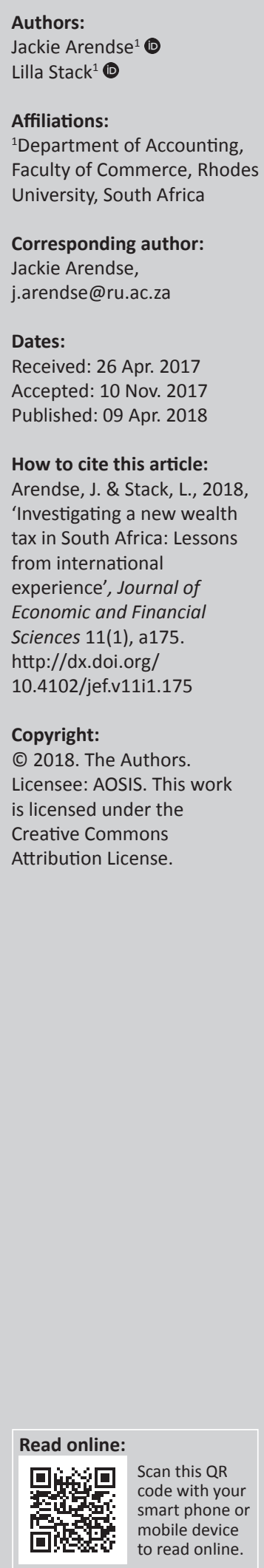

In recent years, there has been an increasing focus on new sources of taxation, including wealth tax. In South Africa, two phenomena have driven the focus on wealth tax. Firstly, the need for additional tax revenue to fund an ongoing and growing budget deficit, exacerbated by a prolonged period of low economic growth, rising government debt and a very small base of individual taxpayers. Secondly, the fact that South Africa has one of the most unequal societies in the world. The dual demands of increased tax revenue and economic inequality have converged around wealth tax as a possible panacea to both problems. Although South Africa has a long history of wealth transfer tax in the form of estate duty and donations tax, there has never been a tax on the net wealth holdings of individuals during their lifetime. Internationally, numerous countries have used wealth tax in various forms, including inheritance tax, gift tax, recurrent wealth tax and non-recurrent wealth tax. This study examines some of the international experiences with these three categories of wealth tax, seeking lessons and experiences that can inform the debate around the viability of a new wealth tax in South Africa

\section{Introduction}

Tax exists as a means of generating revenue to fund government expenditure. As tax has become more prevalent over the last century, it has also been used increasingly as a policy tool to address economic deficiencies and influence human behaviour. For example, tax on alcohol, tobacco products and plastic bags are intended to curb consumption of these products, and tax incentives are given to promote energy savings and the use of environment-friendly energy alternatives. Thus, the role of tax has been expanded beyond that of mere revenue generation.

There are a vast number of different types of taxes but essentially they fall into three main groups: tax on income, on consumption and on assets or wealth. Wealth tax is usually motivated by the need to address one or both of the two primary needs, namely, the need to address economic imbalances and the need for additional tax revenue. South Africa faces a dual challenge of continuing budget deficits in the face of very low economic growth, placing pressure on sustainable growth in tax revenue, and high inequality, with a Gini coefficient of 65 which places it at the forefront of the most unequal societies in the world (World Bank 2014). The question of whether a new form of wealth tax should be introduced in South Africa thus becomes compelling in the face of these challenges. The hope of proponents for a new wealth tax is that such a tax will address the prevailing economic inequality; however, the introduction of a new wealth tax carries with it a range of risks. Some, such as the risk of capital flight, low tax yields and increased tax avoidance are known but other unknown risks do exist. Although there are arguments both for and against a new wealth tax in South Africa, as discussed later in this article, there is general agreement that the introduction of such a tax could impact negatively on the economy. Specific concerns are that a new wealth tax may yield little revenue, which may be offset by the necessarily substantial set-up and administration costs, it may drive capital out of the country, depriving the country of much-needed capital and causing an erosion of the overall tax base, and it may dis-incentivise entrepreneurship and wealth-building. Whether the economic set back and costs can be justified as being a necessary and worthwhile investment in pursuit of a greater long-term goal is a key consideration in the overall evaluation of whether such a new tax would be in the best interests of the country.

An evaluation of the possible introduction of a new wealth tax in South Africa requires the consideration of many aspects, one of which is the experience of levying wealth tax in other countries. As several countries have introduced, and abandoned, wealth tax in recent years, the international experience is an important aspect that must be considered as it may offer lessons that, if recognised and learnt, may save considerable cost and disruption to the South African economy. 
This article provides a cross-country synopsis of the international experience of levying wealth tax on individuals with the objective of finding lessons that may be learnt from those experiences and which may inform the debate around whether or not to introduce a new wealth tax in South Africa. The study was conducted by identifying countries that have used wealth tax at some stage over the review period and then exploring archival records and literature to find descriptions of the wealth tax systems that existed and factors that informed policy decisions involving the introduction or termination of wealth tax

The article proceeds as follows. The 'Research context' section sets the context for the research, describing what is meant by a wealth tax and the arguments for and against wealth tax. The section on 'Wealth tax in South Africa' provides a brief overview of the wealth tax experience in South Africa. The section on 'The international experience of wealth tax' explores the international experience of levying wealth tax. The section on 'Conclusion and recommendations' explains the lessons that can be learnt by South Africa from the international experience of levying wealth tax.

\section{Research context}

Wealth tax is the tax imposed on wealth, as opposed to tax on income or consumption. A wealth tax has been described by Ernst and Young (2015) as:

a levy based on the aggregate value or stock of all assets belonging to an individual (or in some cases, a household), including ... housing, cash and other bank deposits, money funds, savings in insurance and pension plans, investment in non-owner-occupied real estate, unincorporated businesses, corporate stock, financial securities and personal trusts. In other words, the assets typically accumulated by the wealthy. (p. 12)

A broad definition of wealth tax includes property tax (Bird 1991:323); however, as property tax is levied at the municipal level in South Africa, this study focuses on the more limited definition of wealth tax which excludes property tax and considers only wealth tax on individuals.

Wealth tax is generally motivated by two main objectives: to raise additional tax revenue that will contribute towards meeting the demands of government spending, and as a redistribution tool to address inequality (McDonnell 2013:5; Schnellenbach 2012:370).

Wealth tax takes various forms but usually fits into three categories: tax on the transfer of wealth (e.g. inheritance tax, gift tax and various types of property transfer tax); tax on the increase in value of wealth, whether realised or unrealised; and tax on existing wealth or net wealth holdings (Chatalova \& Evans 2013). Tax on the net wealth holdings of a person may take the form of a once-off charge (referred to as a nonrecurrent wealth tax), which may be levied on a particular date, or a tax levied on a recurrent basis, for example, annually at other set intervals (referred to as a recurrent wealth tax).
Davies (1984) postulates that income tax, consumption tax and wealth tax have a common basis in that they are all levied on property; however, they are differentiated by the timing of the tax, with income tax being a tax on property when it is first received, consumption tax being a tax on property when it is consumed (at the end of the ownership cycle) and wealth tax being a tax on property in the intervening period of ownership. Income and consumption taxes work well together in many tax systems but whether wealth tax works successfully with income and consumption taxes is open to debate. Wealth tax, in conjunction with income tax, is sometimes perceived as a double tax because the same income that has been the subject of the income tax is then subject to wealth tax once it is invested. Wealth tax can also have a negative effect on consumption tax as it depletes the value of the property of the taxpayer, thereby depleting the consumption tax base. Despite these disadvantages of wealth tax, there are also disadvantages of not having wealth tax, as the absence of a wealth tax allows unconsumed property to remain untaxed and even allows the property to be transferred, untaxed, from one generation to the next, facilitating the preservation of pockets of wealth, which contributes to ongoing or even increased inequality. Wealth tax is seen to have a pivotal role in breaking this perpetuation of wealth holdings as it serves to redistribute wealth away from family dynasties, towards the broader benefit of society.

Proponents of wealth tax typically argue that such a tax provides a solution to the challenges of ongoing continued budget deficits and low economic growth and addresses the huge economic imbalance that persists in most parts of the world by shifting the tax burden away from labour and consumption towards wealth (Bach, Beznoska \& Steiner 2014). Whilst wealth tax may increase the progressivity of a tax system, it is recognised that, as with any redistribution policy, the extent to which wealth tax is truly effective in reducing inequality depends very much on how the tax revenue is spent (Landman 2014).

Boadway, Chamberlain and Emmerson (2010) suggest that a wealth tax can reduce inequality and promote equity in complementing the income tax system as:

taxing income itself is an inadequate yardstick for determining ability to pay taxes and does not take into account the benefits from holding capital over and above the income derived from it. (p. 786)

Wealth tax can also support compliance as it provides the opportunity for obtaining disclosures from taxpayers which can be cross-checked with information provided in other tax returns (Boadway et al. 2010:786:531; McDonnell 2013:7; Rudnick \& Gordon 1996:4; Shakow \& Shuldiner 2000).

Evans (2013) lists five arguments in support of wealth tax which expands on this argument. Firstly, he opines that wealth tax provides an opportunity to achieve horizontal equity, which is the equal treatment of those with equal capacity, by supplementing income tax in the case of those who have 
taxable wealth capacity. Secondly, wealth tax promotes vertical equity through progressive taxation of those with wealth. Thirdly, wealth tax promotes efficiency in that imposing a charge on wealth regardless of the income generated by the underlying assets encourages assets to be used more productively. Fourthly, wealth tax assists in tax administration by providing useful information on assets, which aids in reducing evasion of other types of tax. Lastly, wealth tax can provide useful signals for society that the poor have not been overlooked. These attributes are valid in themselves, but their value can only be realised if the wealth tax yields an economically viable amount of tax revenue, and it is on the point of revenue-creating potential that much of the criticism of wealth tax is focused on.

Opponents of wealth tax argue that the implementation of such a tax would not make any significant contribution towards addressing economic imbalances that have prevailed for decades, if not centuries, and may not be economically justified owing to the very small tax base in terms of both the number of potential taxpayers and the asset base that would remain after taking into account the inevitable exemptions and exclusions (Duff 1993; Rakowski 1999; Schnellenbach 2012). A further depletion of the potential tax yield results from the associated administration and collection costs, as noted by Rakowski (1999) and Schnellenbach (2012). In a sense, wealth tax could become self-defeating if successful and the desired effect of reducing pockets of wealth is achieved, as this would result in a contraction of the tax base.

Much of the policy debate around wealth tax is concerned with the questions of the scope of the tax, or put simply, the question of 'what is wealth?' Generally, 'wealth' for this purpose is concerned with a person's total assets. Determining which assets come within the scope of a wealth tax is one of the fundamental components of the framework of a wealth tax system. The starting point is to include all assets owned by the targeted taxpayer. Countries usually have exemptions, which exclude assets such as the person's primary home, main motor vehicle, household assets, personal effects, including clothing and jewellery, and retirement savings. In the review of wealth tax internationally in the section "The international experience of wealth tax' of this article, it is evident that countries with recurrent wealth tax usually have a tax-free threshold below which the wealth tax does not apply. The assets to be excluded and the tax-free threshold are key aspects to be considered in the design of a wealth tax. Other aspects to be considered are the rate, the scope and technical features such as how assets should be valued. Another policy challenge is how to determine the value of the assets that are the subject of a wealth tax. As will be seen in the international comparison in the section "The international experience of wealth tax', this aspect has proven to be a costly administrative exercise both for the taxpayer and for revenue enforcement. A further policy decision is regarding how regularly should the tax be levied. The main compliance challenge is ensuring that all assets and values are accurately disclosed by taxpayers, as many forms of wealth, such as paintings, jewellery, diamonds and coin collections, are easy to hide and undervalue. Policy compromises such as excluding household assets make compliance easier to achieve but reduce the tax base (Evans 2013).

It is evident from this brief overview that wealth tax systems are inherently complex. Designing and drafting the legislation, obtaining appropriate valuations of assets and following the compliance process of declaring wealth and determining the wealth tax liability has proven to involve substantial administrative costs in many countries. For some countries, the costs have proved so punitive that they have abandoned the system of wealth tax.

Before exploring the international experience of levying wealth tax, it would be appropriate to briefly consider the South African experience of levying wealth tax, which is discussed in the next section.

\section{Wealth tax in South Africa}

South Africa currently has wealth transfer tax in the form of estate duty (levied in terms of the Estate Duty Act, No. 45 of 1955), donations tax (levied in terms of sections 54 to 56 of the Income Tax Act, No. 58 of 1962), wealth transfer tax in the form of transfer duty (levied in terms of the Transfer Duty Act, No. 40 of 1949) and securities transfer tax (levied in terms of the Securities Transfer Tax Act, No. 25 of 2007). South Africa has never had a tax on wealth holdings.

Although South Africa wrestles with deeply embedded and persistent inequality, with the highest Gini coefficient out of 157 countries measured by the World Bank (2014), the tax and economic policies used to address inequality have thus far focused on redistribution through a progressive tax system and an expenditure programme that has focused on providing resources for the poor. In recent years, the progressivity of the tax system has been increased further by raising the maximum marginal tax rate on high-income earners, increasing the dividends tax rate (which applies mainly to individual investors) and increasing the effective capital gains tax rate. The monetary effect of these amendments, which were introduced in 2016 and 2017, is yet to be revealed, but it is expected that they will yield additional tax revenue; however, because of a very small and narrow tax base, it is unlikely that the additional revenue will be significant.

With the prevailing inequality at unacceptable levels and an ever-widening budget deficit, there is renewed focus in South African policy debates on wealth tax as a possible panacea for the dual challenge of economic inequality and tax revenue shortfalls.

Although the introduction of a new wealth tax has not yet been announced in South Africa, there is growing speculation at the time of writing this article that such a development may materialise. In October 2014, the Minister of Finance warned of the need for additional measures to address the ongoing budget deficit and rising government debt, stating 
that the country had reached the turning point where 'fiscal consolidation can no longer be postponed' (Republic of South Africa 2014:10). Over the next few years, higher revenue targets have been set in the annual budgets (Republic of South Africa 2016; Republic of South Africa, National Treasury 2017), but as economic growth has slowed, these targets have become increasingly unattainable. The Minister of Finance stated in the 2016 budget speech (Republic of South Africa 2016:16) that 'current taxes on wealth are under review by the Davis Committee', referring to the Davis Tax Committee, which was instated in 2013 with the mandate to review South Africa's tax policy and its role in supporting the objectives of the National Development Plan (Republic of South Africa 2013:4). The Terms of Reference of the Davis Tax Committee include the review of the 'progressivity of the tax system and the role and continued relevance of estate duty to support a more equitable and progressive tax system', including 'the interaction between capital gains tax and the estate duty' (Davis Tax Committee 2013:online). In the Second Interim Report on Estate Duty issued by the Davis Tax Committee (Davis Tax Committee 2016:7), the Committee recommended that 'further investigation should be conducted into the implementation of wealth taxes in $\mathrm{SA}^{\prime}$ and indicated that this would be addressed in a separate report of the Committee. To date, this separate report on wealth tax has not yet been published; however, in the context of anticipated tax hikes and government's pursuit of new tax revenue sources, there is much speculation that a new type of wealth tax may be introduced in South Africa at some stage (e.g. Jooste 2014; Lamprecht 2014; Teuchert 2014; Williams 2011; Zerbst 2013).

Proponents of wealth tax in South Africa argue that the introduction of such a tax would provide a means to address the extreme economic inequality that exists. On the contrary, there is a risk that the implementation of a new wealth tax would not generate sufficient additional tax revenue to enable any significant contribution to be made towards addressing the economic imbalances that have prevailed for more than two centuries owing to the very small tax base that exists in South Africa. Statistics produced by the South African Revenue Service (2016; Table A2.1.1) indicate that there were only 31566 individual taxpayers (comprising $0.7 \%$ of all assessed taxpayers) with taxable income exceeding R2 million for the 2015 year of assessment. Although not a definitive indicator of the potential wealth tax base, this does indicate that the revenue yield from a wealth tax is unlikely to be significant. There is a risk that any wealth tax revenue could be negated by the administration costs and the loss of other tax revenue that could result from the depletion of the overall tax base caused by capital expatriation and the disincentive for entrepreneurship and wealth-building. Furthermore, a new wealth tax could prove to be a disincentive to private giving which currently channels substantial funds to social projects [e.g. wealthy entrepreneur Patrice Motsepe's pledge of R10 million to rural communities (Sowetan 2013)]. There are concerns that the negative impact of a new wealth tax could have a deep and lasting impact on the economy.
Teuchert (2014), for example, has the view that a wealth tax would do 'more harm than good' and 'wealthy individuals will almost certainly consider leaving South Africa to escape a harsh tax regime'. Veritas Wealth Management (2014) suggests that a new wealth tax 'will either encourage honest people to become dishonest or it will push entrepreneurs further away from South Africa'.

A careful examination of the possible merits and disadvantages and unintended consequences of a new wealth tax in South Africa must precede any policy decisions on the introduction of such a tax. One aspect of this examination involves a review of the historical experiences of similar taxes in other countries, which is discussed in this article. The information gleaned from the international review provides data on others' experiences of levying wealth tax, which may inform the investigation into the viability of introducing a new wealth tax in South Africa. Such a study also adds to the body of knowledge on wealth tax as very little research exists on wealth tax in developing countries (Chatalova \& Evans 2013).

The international experience of wealth tax is not new. Wealth tax has existed in various forms for decades, but experience has shown that wealth tax does not always meet its goals and several countries have introduced wealth tax only to abandon it some years later. The international experience of wealth tax is informative, providing examples of both successful and unsuccessful implementations of wealth tax and offering valuable lessons that can inform the South African debate on the viability of a new wealth tax. The section on 'The international experience on wealth tax' provides an overview of the international experience with wealth tax.

\section{The international experience of wealth tax}

The international experience of wealth tax is reviewed with the objective of observing trends in the implementation of wealth tax in various countries over the last few decades and identifying reasons for changes that have been made, whether by way of implementing new wealth tax, changing existing systems or abandoning certain types of tax. The overarching objective is to seek lessons that can be learnt from successes and failures in the implementation of wealth tax in other countries to inform the policy debate around the possible introduction of a new wealth tax in South Africa.

Countries that have had some form of wealth tax in the last four decades were identified from statistical data published by the Organisation for Economic Co-operation and Development (OECD 2015), which covers the period from 1965 to 2015. Having identified which countries introduced and/or abandoned wealth tax over this period, archival records and the literature were studied to obtain details of the types of wealth taxes that existed and reasons for introducing and abandoning wealth tax. South Africa is not a member of the OECD but forms part of the association of five countries 
referred to as 'the BRICS group' (comprising Brazil, Russia, India, China and South Africa) and the wealth tax experience of this group of countries was sought from the literature and government publications.

Having reviewed the wealth tax experience among the 40 OECD and BRICS countries, the study uses the OECD statistical data (2015) to compare the tax revenue yield from wealth tax in the OECD member countries across the 41-year period for which data are available. This is compared with the South African data over a similar period (data for the other BRICS countries was unavailable).

Wealth tax has been utilised in many countries around the world, in different forms and at various times over the last few decades. Wealth tax revenue collections were more significant in the early 20th century, but the revenue generated from wealth tax has been eclipsed by the exponential growth of income and consumption taxes over the ensuing years (Chatalova \& Evans 2013:444). Duff (1993:7) observes that 'British estate tax revenues accounted for $16.1 \%$ of total revenues from 1908 to 1915, and United States gift and estate taxes totalled roughly $10.0 \%$ of federal revenues in $1936^{\prime}$, but post-war trends have seen wealth tax dwindle in terms of its contribution to the total tax revenue such that in 2015 wealth tax contributed only $0.2 \%$ of the gross domestic product (GDP) of the United Kingdom (equating $0.7 \%$ of the total tax revenue) and only $0.1 \%$ of the GDP of the United States (equating $0.5 \%$ of the total tax revenue). Although the decline is also evident in other countries and several countries have abandoned wealth tax, there have still been some attempts to introduce wealth tax in recent years. Ernst and Young report that (2015):

Over the past few decades, until the global financial crisis, recurrent taxes on net wealth were in decline in many countries. Austria, Denmark, Finland, Germany, the Netherlands and Sweden had all repealed such taxes. More recently, though, several countries have either introduced or seriously debated such taxes. In some jurisdictions, their use has been on a temporary basis - often in tandem with a solidarity surcharge on income. In other cases, wealth taxes have been introduced without time limitation, although their existence may ultimately be short-lived as national economies recover and generate more revenue. (pp. 12-13)

Table 1 provides an overview of the various types of wealth tax that have existed in each of the OECD countries, indicating the types of tax that have existed at various stages during the 41-year review period and those that are currently in place. Wealth tax identified in the OECD statistics (OECD 2015) is grouped into the following three categories: estate, inheritance and gift taxes; recurrent tax on net wealth; and non-recurrent tax on net wealth. The table indicates the existence of each of these types of wealth tax for each of the OECD and BRICS countries.

As indicated in Table 1, all OECD member countries other than Estonia and Israel, thus, 33 OECD countries in total, and 4 out of the 5 BRICS countries, had some form of inheritance, estate, gift or net wealth tax at some stage during the 41-year review period. In 2015, however, only 25 OECD member countries and 2 of the BRICS countries had one or the other form of wealth tax. The eight OECD countries that had, but do not currently have any wealth tax, are Australia, Austria, Canada, Mexico, New Zealand, Portugal, the Slovak Republic and Sweden. These countries have introduced and subsequently abandoned wealth tax for various reasons, the most prominent being the high costs of administration and compliance (Schnellenbach 2012:376), including the cost of valuing assets, increased avoidance, evasion to such an extent that it has threatened the income tax base (Schnellenbach 2012:376), increased capital mobility (McDonnell 2013:52) and constitutional challenges (Chatalova \& Evans 2013:445).

The international experiences in each of the three categories of wealth tax (estate, inheritance and gift taxes; recurrent wealth tax; and non-recurrent wealth tax) are discussed below.

\section{Estate, inheritance and gift taxes}

Canada scrapped gift and inheritance taxes in the 1970s and early 1980s because of concerns around the negative impact on the economy and entrepreneurship (Duff 2005), and problems with avoidance and compliance (Chatalova \& Evans 2013:445). The federal estate tax was repealed in 1972 and replaced with death tax levied at the provincial level. Gradually, provinces abandoned the death tax over the next 13 years until the final repeal by Quebec in 1985.

Australia repealed wealth transfer tax in the late 1970s because of compliance and avoidance problems, particularly involving the use of discretionary trusts and the high compliance costs incurred by smaller estates (Chatalova \& Evans 2013:445).

New Zealand abandoned estate tax in 1992 as it became increasingly difficult to prevent the migration of capital, particularly after Australia's repeal of wealth transfer tax (Chatalova \& Evans 2013:446). New Zealand later abolished gift tax in 2011 and currently has no wealth tax (Ernst and Young 2016a:218).

Countries that introduced estate, inheritance and gift taxes for brief periods during the 41-year period covered by the OECD data include Mexico, which introduced death duty for 4 years from 1989 to 1993, the United Kingdom, which added a gift tax to its long-standing inheritance tax for a brief period from 1976 to 1979, and the Slovak Republic, which implemented estate, inheritance and gift taxes for one decade from 1995 to 2004 and has since had no other wealth tax (OECD 2015).

Austria, Norway, Portugal, the Slovak Republic, Sweden and non-OECDcountries, such as Brunei, Hong Kong, Liechtenstein, Macau, Russia and Singapore, have all abandoned inheritance or estate tax since 2000 (Cole 2015; Ernst and Young 2015).

Austria repealed inheritance tax in 2008 owing to concerns about capital flight (Chatalova \& Evans 2013:446; Ernst and Young 2016a:8). 
TABLE 1: Wealth tax in Organisation for Economic Co-operation and Development and BRICS countries.

\begin{tabular}{|c|c|c|c|c|c|c|}
\hline \multirow[t]{2}{*}{ Country } & \multicolumn{2}{|c|}{ Estate, inheritance and taxes } & \multicolumn{2}{|c|}{ Recurrent tax on net wealth } & \multicolumn{2}{|c|}{ Non-recurrent tax on net wealth } \\
\hline & Any time since 1965 & Current (2017) & Any time since 1965 & Current (2017) & Any time since 1965 & Current (2017) \\
\hline Australia & Yes & No & No & No & No & No \\
\hline Austria & Yes & No & Yes & No & Yes & No \\
\hline Belgium & Yes & Yes & No & No & No & No \\
\hline Brazil & Yes & Yes & No & No & No & No \\
\hline Canada & Yes & No & No & No & No & No \\
\hline Chile & Yes & Yes & No & No & No & No \\
\hline China & No & No & No & No & No & No \\
\hline Czech Republic & Yes & Yes & No & No & No & No \\
\hline Denmark & Yes & Yes & Yes & No & No & No \\
\hline Estonia & No & No & No & No & No & No \\
\hline Finland & Yes & Yes & Yes & No & No & No \\
\hline France & Yes & Yes & Yes & Yes & Yes & No \\
\hline Germany & Yes & Yes & Yes & No & No & No \\
\hline Greece & Yes & No & Yes & Yes & Yes & No \\
\hline Hungary & Yes & Yes & Yes & No & No & No \\
\hline Iceland & Yes & Yes & Yes & No & No & No \\
\hline India & Yes & No & Yes & No & No & No \\
\hline Ireland & Yes & Yes & Yes & No & No & No \\
\hline Israel & No & No & No & No & No & No \\
\hline Italy & Yes & Yes & Yes & Yes & No & No \\
\hline Japan & Yes & Yes & No & No & No & No \\
\hline Korea & Yes & Yes & No & No & No & No \\
\hline Latvia & Yes & Yes & No & No & No & No \\
\hline Luxembourg & Yes & Yes & Yes & No & No & No \\
\hline Mexico & Yes & No & No & No & No & No \\
\hline Netherlands & Yes & Yes & Yes & No & No & No \\
\hline New Zealand & Yes & No & No & No & No & No \\
\hline Norway & Yes & No & Yes & Yes & No & No \\
\hline Poland & Yes & Yes & No & No & No & No \\
\hline Portugal & Yes & No & No & No & No & No \\
\hline Russia & Yes & No & No & No & No & No \\
\hline Slovak Republic & Yes & No & No & No & No & No \\
\hline Slovenia & Yes & Yes & No & No & No & No \\
\hline South Africa & Yes & Yes & No & No & No & No \\
\hline Spain & Yes & Yes & No & No & Yes & Yes \\
\hline Sweden & Yes & No & Yes & No & No & No \\
\hline Switzerland & Yes & Yes & Yes & Yes & No & No \\
\hline Turkey & Yes & Yes & Yes & No & No & No \\
\hline United Kingdom & Yes & Yes & Yes & No & No & No \\
\hline United States & Yes & Yes & Yes & No & No & No \\
\hline Total countries & 40 & 40 & 40 & 40 & 40 & 40 \\
\hline Total yes & 37 & 25 & 19 & 5 & 4 & 1 \\
\hline OECD yes & 33 & 23 & 18 & 5 & 4 & 1 \\
\hline BRICS yes & 4 & 2 & 1 & 0 & 0 & 0 \\
\hline
\end{tabular}

OECD, Organisation for Economic Co-operation and Development; BRICS, five countries referred to (comprising Brazil, Russia, India, China and South Africa).

Norway abolished inheritance and gift taxes in 2014 in a policy shift to improve economic growth (Ernst and Young 2016b:1038). In announcing the abolition of the inheritance tax, the Minister of Finance stated (Ernst and Young 2015:15), 'We are starting the work to turn the Norwegian economy in a better direction, where we acknowledge that value must be created before it can be shared'. Although it no longer has inheritance and gift taxes, Norway has retained a recurrent wealth tax, which is discussed later in this article.

Sweden repealed inheritance and gift taxes in 2004. Inheritance and gift taxes had existed in Sweden in various forms since the 17 th century with rates reaching a peak of $70.0 \%$ in 1983
(Ydstedt 2016:2). According to Chatalova and Evans (2013:445), the wealth tax system in Sweden had 'inconsistencies in the treatment of private wealth and operating assets' which led to 'inefficient and inequitable outcomes'. Denk states (2012:18) that the wealth tax was abandoned to avoid the cumulative taxation of capital income and wealth and because 'it suffered from exceptions that created loopholes and encouraged tax planning'.

Hungary introduced an inheritance and gift tax in 1991; however, in 2006, it repealed the inheritance tax for close relatives and only retained an $18 \%$ inheritance tax for unrelated heirs (Cole 2015). Tax revenue collections from inheritance and 
gift taxes decreased from $0.07 \%$ of GDP in 2006 to $0.02 \%$ of gross domestic production in 2010 and have remained at $0.02 \%$ from 2010 to 2015 (OECD 2015).

Iceland, on the contrary, has had death duty in place since 1980 , levied at a rate of $10.0 \%$ on the value of an inheritance from an Icelandic resident exceeding ISK1 500000 (KPMG 2016).

The Netherlands has had inheritance and gift taxes in place since 1956, which are levied at rates ranging from 10.0\% to $40.0 \%$, depending on the proximity of the relationship between the deceased and the heir and the value of the inheritance (Ernst and Young 2016a:209).

The US federal estate tax is levied at rates of up to $40 \%$ but has a high threshold (USD 5.45million), resulting in only $0.2 \%$ of estates being subject to the tax (Huang \& Cho 2016:2).

BRICS countries have mixed experiences with estate, inheritance and gift taxes. Brazil levies a tax on the transfer of assets to a donee or the heirs of an estate at rates of up to $8 \%$ (Ernst and Young 2016b:166). Russia abolished inheritance and gift taxes in 2006 and currently has no wealth tax (Ernst and Young 2016a:264). India scrapped estate duty in 1985 and has no inheritance tax. The receipt of gifts is subject to income tax in the donees' hands (Ernst and Young 2016a:140). China has never implemented estate duty, inheritance or gift tax and has no wealth tax (Ernst and Young 2015:16). As discussed in the section on 'Wealth tax in South Africa', South Africa has had estate duty and donations tax since 1955.

This brief synopsis indicates that the use of estate, inheritance and gift taxes has waned over the last four decades, with 10 OECD countries and 2 BRICS countries having scrapped these taxes over the review period. Of the countries that have scrapped estate, inheritance and gift taxes, two countries, Greece and Norway, have replaced these taxes with a recurrent wealth tax system, which is discussed in the next section of this article.

Although these taxes have lost favour, estate, inheritance and gift taxes remain more popular than other types of wealth tax. Table 1 indicates that 23 of the OECD countries still have inheritance or estate taxes, whereas only 5 have recurrent wealth tax. Seven OECD countries and one BRICS country have abandoned recurrent wealth tax during the 41-year review period. A brief review of the countries' experiences with recurrent wealth tax is discussed in the following section.

\section{Recurrent wealth tax}

France, Greece, Italy, Norway and Switzerland are the only OECD countries with existing recurrent wealth tax on individuals, whilst Luxembourg levies recurrent wealth tax on companies only (OECD 2015).

Francois Mitterand, the leader of the Socialist Party at the time, introduced a recurrent wealth tax, the Impot sur les
Grandes Fortunes (IGF), in France in 1982, taxing assets above 10 million francs at a flat rate of $1.5 \%$ (Chibber 2014). The IGF was introduced in addition to the inheritance and gift taxes that have existed in France for many years and levied at rates ranging from $5 \%$ on a small estate to $45 \%$ on inheritances and gifts above EUR1 805678 and 60\% on non-blood-related heirs including a non-married partner (Ernst and Young 2016a:103). The IGF was repealed by Jacques Chirac's Republican government in 1987 but was subsequently reinstated in the form of the Impôt de solidarite sur La Fortunes (ISF) in 1989 following the re-election of Mitterand as president. Ernst and Young reported that more than 500 people emigrated from the country in 2006 because of the ISF (Ernst and Young 2015:13) and other reports put the number even higher, with a reported loss of capital of some EUR 2.8 billion (Connexion 2010). The ISF is levied on all assets, excluding pensions, vintage items more than a century old, literary estate rights and forestry', at rates ranging from $0 \%$ to $1.5 \%$, with the highest rate applying to net wealth exceeding EUR 10 million (Ernst and Young 2016a:104). In spite of the ISF, inequality in France has not reduced. The Gini index, which measures inequality of income, showed an upward trend from $28.7 \%$ in 2001 to $29.2 \%$ in 2007 and $29.4 \%$ in 2013 (OECD 2017). Wealth inequality, measured as a percentage held by the top decile, increased from to $51.1 \%$ in 2007 to $53.1 \%$ in 2014 (Credit Suisse 2014:33).

Norway levies a recurrent wealth tax at a rate of $0.85 \%$, reduced from $1.1 \%$ in 2014, on the net assets exceeding NOK 1400000 (Ernst and Young 2016a:229). The tax base excludes private pensions and includes only $25 \%$ of the value of owner-occupied property and $40 \%$ of the value of any rental properties (Denk 2012:11).

Switzerland has 27 tax jurisdictions comprising each of the 26 cantons as well as the federal tax system. Each canton has autonomy and sovereignty, and tax legislation varies across cantons, with most levying inheritance and gift taxes on the net share of assets received by the heir or donee with an exemption for spouses and direct descendants. Two cantons, Graubünden and Solothurn, have estate tax, levied at a flat rate on the net value of the deceased's estate (Ernst and Young 2016a:321). Wealth tax is levied at the cantonal level on net worldwide assets excluding household goods and the rates vary between cantons (Ernst and Young 2016a:321-322). For example, in Zurich, the rate is $0.3 \%$ on net assets exceeding CHF3 235000 and in Geneva the rate is $4.5 \%$ on net assets exceeding CHF1 682 068. Capital gains from sales of movable assets are not taxed at either the federal or cantonal level, whilst capital gains realised on the sale of immovable property are subject to a separate tax in all cantons (Ernst and Young 2016b:1333).

Austria, Denmark, Finland, Germany, Hungary, Iceland, India, Ireland, Luxembourg, the Netherlands, Sweden, Turkey, the United Kingdom and the United States are the 14 countries shown in Table 1 to have scrapped recurrent wealth tax during the review period. 
Administrative complexities and inefficiencies were the main reasons cited for Austria scrapping its recurrent wealth tax (Ristea \& Trandafir 2010:304).

Germany scrapped recurrent wealth tax in 2006, mainly owing to 'administrative and valuation issues' (Chatalova \& Evans 2013:445) and concerns around avoidance after the German Federal Constitutional Court declared the net wealth tax unconstitutional on the basis that different valuations for different properties 'were in violation of equality of law principles' (Chatalova \& Evans 2013:445).

Hungary introduced a limited wealth tax, referred to as a 'luxury goods tax', on investment properties, luxury boats, aircraft and sports cars on 01 January 2010 (Chatalova \& Evans 2013:448). Shortly after the legislation was passed, the Constitutional Court ruled that the self-assessment basis of the tax on investment properties was unconstitutional and, thus, properties were excluded from the scope of the tax (Ristea \& Trandafir 2010:303). The luxury goods tax was intended to be paid biannually on the remaining items but did not prove successful and the tax was discontinued less than 1 year after implementation.

Iceland abolished recurrent wealth tax in 2006 as part of a 'series of pro-growth tax reforms' (Gissurarson \& Mitchell 2007:3), but following the financial crisis of 2008 found it necessary to introduce a limited net wealth tax which applied, as a temporary measure for a 4-year period, to financial assets, business assets and real estate. The limited net wealth tax was selected as a revenue-generation mechanism that would have the least impact on economic growth and was motivated by an urgent need for tax revenue (New Statesman 2012). It was introduced in 2010 at a rate of 1.25\% (Escolano et al. 2010:2) and the rate was increased to $1.5 \%$ a year later. Foreign exchange controls that had been introduced as an emergency measure at the time of the 2008 financial crisis prevented the flight of capital that might otherwise have occurred following the introduction of the wealth tax. The wealth tax did not have a noticeable impact on tax revenue, which continued to yield 0.1\% of GDP per year from 2011 to 2015 (OECD 2015). As exchange controls were eased, it was recognised that movable assets such as cash and financial securities were likely to become 'much more sensitive to the tax burden' and 'wealthy Icelandic taxpayers would be likely to leverage their assets to avoid the wealth tax or, if the assets were liquid, move them offshore' (Daniel et al. 2011:27). Concern around capital flight was therefore one of the main motivators in the decision to allow the wealth tax to expire. The tax was replaced with a flat tax rate on capital returns.

Ireland had a recurrent wealth tax between 1975 and 1978, which was motivated as a means of addressing extreme inequality of wealth following a report that $5.0 \%$ of the population held $71.0 \%$ of the country's wealth $(\mathrm{McD}$ Donnell 2013:23). The tax was levied at rates between $1.0 \%$ and $2.5 \%$ and had a modest threshold, minimal exemptions and no ceiling. The tax was short-lived, with low revenue yields that did not justify the administration costs, and was scrapped when there was a change in government (Bird 1991:327).

The Netherlands repealed recurrent net wealth tax in 2001 amid concerns about high collection costs (Ristea \& Trandafir 2010:304) and capital flight (Chatalova \& Evans 2013:446).

Until 2016, India was the only BRICS country with a recurrent wealth tax (Chatalova \& Evans 2013:436). India introduced an annual wealth tax in 1957 with the twin objectives of reducing inequality and promoting compliance by way of cross-checking the information declared for income tax purposes (Government of India Ministry of Finance 2015:16). The wealth tax was levied at a rate of $1.0 \%$ on net wealth exceeding INR3 million (approximately \$48 000) (Ernst and Young 2015:13) until it was discontinued from 01 April 2016 and replaced with a $2.0 \%$ surcharge on high-income earning taxpayers (Singh 2015). Prior to the discontinuance, India was the only non-OECD country that had a recurrent wealth tax on individuals. The Explanatory Statement to the Finance Bill 2015 (Government of India Ministry of Finance 2015:16) indicated that the main reasons for discontinuing the wealth tax were the low tax revenue and high compliance costs. As a result, the Indian Ministry of Finance proposed that increasing the tax burden on high-income taxpayers could be achieved by levying an income tax surcharge rather than having a separate wealth tax, as a surcharge was regarded as (2015:16) 'easy to collect and monitor and also does not result into any compliance burden on the assessee and administrative burden on the department'.

This review indicates that there has been a general move away from recurrent wealth tax over the last 4 decades, with 14 countries having scrapped this tax. The main reasons cited for scrapping this tax was constitutional challenges (Hungary and Germany); inefficiencies (Austria, Hungary, Iceland, Ireland, India); administrative complexity and high collection costs (Austria Germany, Ireland, India, Netherlands), tax avoidance (Germany), concerns around the negative impact on the economy (Iceland) and capital flight (Germany, Netherlands). In 2016, only five countries still had recurrent wealth tax in place.

Even scarcer than recurrent wealth tax is non-recurrent wealth tax. Spain is the only OECD member country to have a non-recurrent wealth tax, and for very specific reasons, as is discussed in the next section.

\section{Non-recurrent wealth tax}

Spain, the only OECD country with a non-recurrent wealth tax, has had various forms of wealth tax in place at different times over the review period. An inheritance tax has been in place since 1973 and both a gift tax and a non-recurrent wealth tax were then added in 1981. Spain subsequently abandoned the non-recurrent wealth tax in 2008 and then reintroduced it in a slightly different form in 2011 in what was stated to be a temporary measure to generate a new tax revenue source (Chatalova \& Evans 2013:448). This followed 
the Eurozone financial crisis which caused the budget deficit climb to $11.2 \%$ of GDP, triggering the introduction of austerity measures (Ristea \& Trandafir 2010:301). The wealth tax was originally introduced for a 2-year period from 2011 to 2012 but was subsequently extended for a further 4 years through to 2016 and indications are that the tax will continue to be extended (Ernst and Young 2016a:301). Inheritance tax is levied at rates ranging from $0.2 \%$ to $2.5 \%$ and exemptions apply based on the age of the heir and the proximity of relationship to the deceased (Ernst and Young 2016a:305).

Overall, the international wealth tax experiences are varied, but a common feature is that very few countries have introduced and maintained wealth tax in the last few years, despite the increased call for wealth tax in the face of an unrelenting increase in wealth inequality. Generally, the trend has been to stay away from wealth tax except when the levy of this tax has been necessitated by economic crises, wherein wealth tax has been introduced as a temporary measure.

The revenue collections from wealth tax has also not shown any strong positive revenue yield trends, as is discussed in the next section, which examines wealth tax collections over the last four decades.

\section{Wealth tax revenue collections}

Wealth tax collections are measured in the OECD statistics (OECD 2015) as a percentage of the GDP of each member country and an overall average is produced, which is depicted in Figure 1.
Figure 1 indicates a general decline in wealth tax collections in the OECD countries over the last 41 years. On an average, across all OECD countries, wealth tax contributed $0.6 \%$ of GDP in 1965 and this contribution had dropped to $0.3 \%$ of GDP by 2014 (some data for 2015 were not yet available at the time of writing). Countries whose wealth tax contributed a greater proportion of GDP in 2015 compared to 1965 are Belgium (an increase of $0.3 \%$ ), Chile (an increase of $0.1 \%$ ), France (an increase of $0.6 \%$ ), Iceland (an increase of $0.1 \%$ ), Japan (an increase of $0.3 \%$ ), Korea (an increase of $0.3 \%$ ), Luxembourg (an increase of $0.3 \%$ ), Spain (an increase of $0.4 \%$ ) and Switzerland (an increase of $0.6 \%$ ). Three of these countries (France, Iceland and Switzerland) had a recurrent wealth tax in 2015 and Spain had a non-recurrent wealth tax, which contributed to the increase in the wealth tax contribution. Belgium's wealth tax contribution increased from $0.4 \%$ of GDP in 1965 to $0.7 \%$ in 2015 owing to increased collections from inheritance and gift taxes following an increase in the tax rates and a broadening of the tax base (OECD 2015).

The OECD statistics on tax revenue for individual member countries indicate very low revenue yields from wealth tax generally, as is shown in Table 2, which illustrates that revenue collections from wealth tax in OECD countries averaged only $0.4 \%$ of GDP over the 41 -year period from 1965 to 2015 . The average for all OECD countries was $0.3 \%$ of GDP in 2014 (some data for 2015 was not yet available at the time of writing and this is indicated as ' $N / A^{\prime}$ in the table), indicating that the yield of wealth tax revenue as a percentage of GDP in OECD countries has declined in recent years.

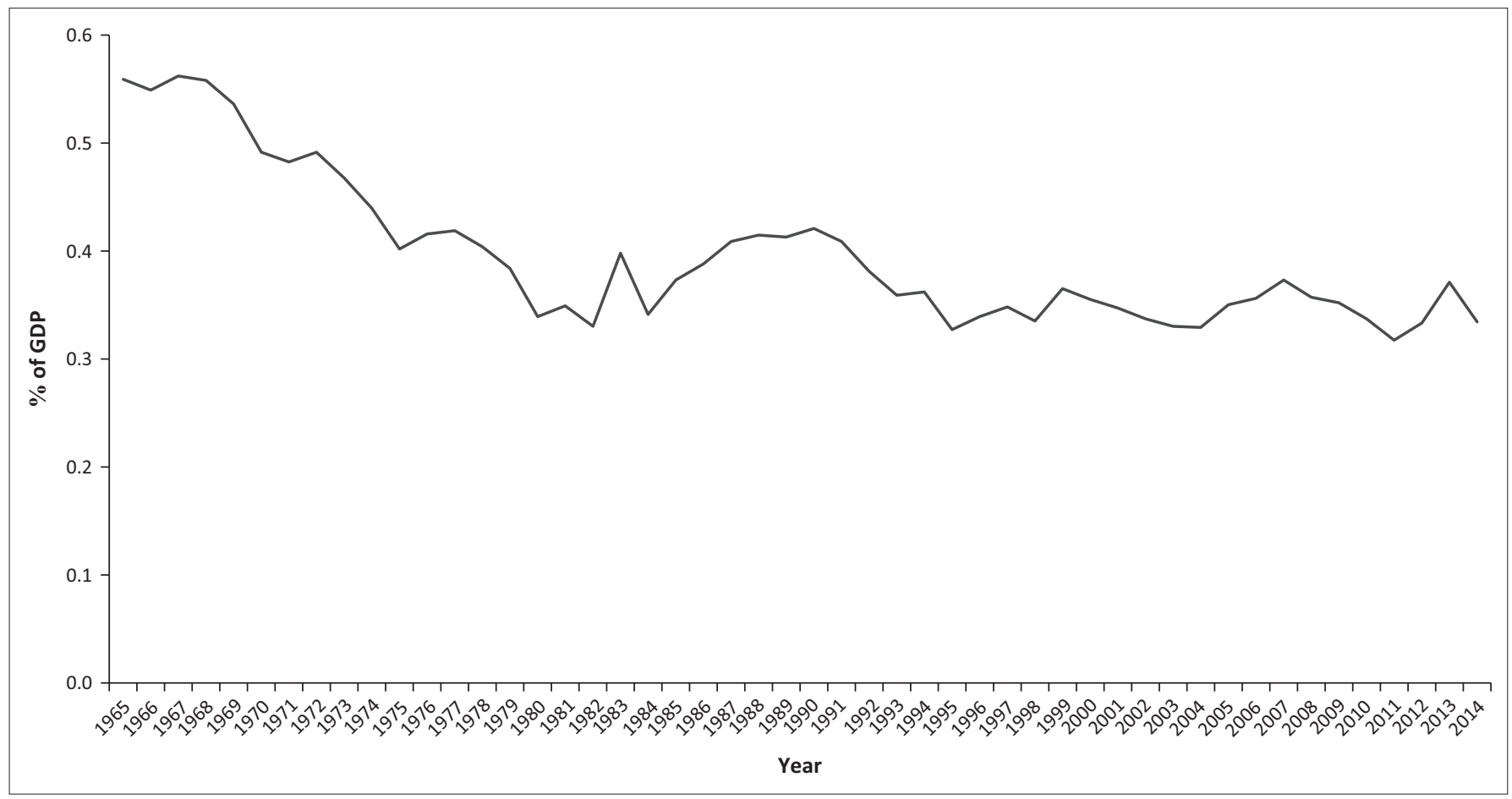

OECD, Organisation for Economic Co-operation and Development; GDP, gross domestic product.

FIGURE 1: Wealth tax on individuals as a percentage of gross domestic product: OECD average. 
TABLE 2: Wealth tax in Organisation for Economic Co-operation and Development countries and South Africa.

\begin{tabular}{|c|c|c|c|c|c|c|c|c|c|c|c|}
\hline \multirow[t]{2}{*}{ Country/year } & \multicolumn{9}{|c|}{ Wealth tax as $\%$ of gross domestic product (GDP) } & \multirow{2}{*}{$\begin{array}{l}\text { Total tax revenue as } \\
\% \text { of GDP (2015) }\end{array}$} & \multirow{2}{*}{$\begin{array}{l}\text { Wealth tax as \% of tota } \\
\text { tax revenue (2015) }\end{array}$} \\
\hline & 1965 & 1995 & 2005 & 2011 & 2012 & 2013 & 2014 & 2015 & 41-year average & & \\
\hline Australia & 0.6 & 0.0 & 0.0 & 0.0 & 0.0 & 0.0 & 0.0 & 0.0 & 0.1 & 27.8 & - \\
\hline Austria & 0.3 & 0.1 & 0.1 & 0.0 & 0.0 & 0.2 & 0.1 & 0.0 & 0.2 & 42.8 & 0.0 \\
\hline Belgium & 0.4 & 0.3 & 0.6 & 0.6 & 0.7 & 0.8 & 0.7 & 0.7 & 0.4 & 45.0 & 1.6 \\
\hline Canada & 0.4 & 0.0 & 0.0 & 0.0 & 0.0 & 0.0 & 0.0 & 0.0 & 0.1 & 31.2 & 0.0 \\
\hline Chile & 0.0 & 0.0 & 0.0 & 0.0 & 0.1 & 0.0 & 0.0 & 0.1 & 0.0 & 19.8 & 0.3 \\
\hline Czech Republic & 0.0 & 0.0 & 0.0 & 0.1 & 0.1 & 0.0 & 0.0 & 0.0 & 0.0 & 33.1 & 0.0 \\
\hline Denmark & 0.6 & 0.3 & 0.2 & 0.3 & 0.2 & 0.2 & 0.2 & 0.3 & 0.3 & 49.6 & 0.5 \\
\hline Estonia & 0.0 & 0.0 & 0.0 & 0.0 & 0.0 & 0.0 & 0.0 & 0.0 & 0.0 & 32.4 & 0.0 \\
\hline Finland & 0.3 & 0.2 & 0.4 & 0.2 & 0.3 & 0.3 & 0.2 & 0.3 & 0.3 & 43.8 & 0.7 \\
\hline France & 0.2 & 0.5 & 0.7 & 0.6 & 0.7 & 0.7 & 0.7 & 0.8 & 0.4 & 45.5 & 1.8 \\
\hline Germany & 0.5 & 0.2 & 0.2 & 0.2 & 0.2 & 0.2 & 0.2 & 0.3 & 0.2 & 36.6 & 0.7 \\
\hline Greece & 0.2 & 0.3 & 0.1 & 0.1 & 0.0 & 0.1 & 0.1 & N/A & 0.2 & 35.8 & 0.6 \\
\hline Hungary & 0.0 & 0.0 & 0.1 & 0.0 & 0.0 & 0.0 & 0.0 & 0.0 & 0.0 & 38.2 & 0.1 \\
\hline Ireland & 0.5 & 0.1 & 0.2 & 0.4 & 0.4 & 0.5 & 0.6 & 0.2 & 0.2 & 28.7 & 0.8 \\
\hline Israel & 0.0 & 0.0 & 0.0 & 0.0 & 0.0 & 0.0 & 0.0 & 0.0 & 0.0 & 31.2 & 0.0 \\
\hline Italy & 0.2 & 0.1 & 0.0 & 0.0 & 0.0 & 0.0 & 0.0 & 0.0 & 0.1 & 43.7 & 0.1 \\
\hline Japan & 0.1 & 0.5 & 0.3 & 0.3 & 0.3 & 0.3 & 0.4 & 0.4 & 0.3 & 32.0 & 1.1 \\
\hline Korea & 0.0 & 0.2 & 0.2 & 0.3 & 0.3 & 0.3 & 0.3 & 0.3 & 0.1 & 24.6 & 1.3 \\
\hline Latvia & 0.0 & 0.0 & 0.0 & 0.0 & 0.0 & 0.0 & 0.0 & 0.0 & 0.0 & 28.9 & 0.0 \\
\hline Luxembourg & 0.3 & 0.7 & 0.7 & 0.7 & 0.8 & 0.7 & 0.7 & 0.6 & 0.6 & 38.4 & 1.7 \\
\hline Mexico & 0.0 & 0.0 & 0.0 & 0.0 & 0.0 & 0.0 & 0.0 & N/A & 0.0 & 15.2 & 0.0 \\
\hline Netherlands & 0.6 & 0.4 & 0.3 & 0.2 & 0.2 & 0.3 & 0.2 & 0.2 & 0.4 & 37.5 & 0.6 \\
\hline New Zealand & 0.5 & 0.0 & 0.0 & 0.0 & 0.0 & 0.0 & 0.0 & 0.0 & 0.1 & 32.5 & 0.0 \\
\hline Norway & 0.5 & 0.6 & 0.5 & 0.5 & 0.5 & 0.5 & 0.4 & 0.4 & 0.5 & 38.7 & 1.1 \\
\hline Poland & 0.0 & 0.0 & 0.0 & 0.0 & 0.0 & 0.0 & 0.0 & N/A & 0.0 & 32.1 & 0.0 \\
\hline Portugal & 0.4 & 0.1 & 0.0 & 0.0 & 0.0 & 0.0 & 0.0 & N/A & 0.1 & 34.2 & 0.4 \\
\hline Slovak Republic & 0.0 & 0.0 & 0.0 & 0.0 & 0.0 & 0.0 & 0.0 & 0.0 & 0.0 & 31.2 & 0.0 \\
\hline Sweden & 0.4 & 0.3 & 0.2 & 0.0 & 0.0 & 0.0 & 0.0 & 0.0 & 0.3 & 42.8 & 0.0 \\
\hline Switzerland & 0.8 & 1.0 & 1.1 & 1.0 & 1.0 & 1.0 & 1.1 & 1.4 & 1.0 & 27.0 & 5.3 \\
\hline Turkey & 0.0 & 0.0 & 0.0 & 0.0 & 0.0 & 0.0 & 0.0 & 0.0 & 0.0 & 28.8 & 0.1 \\
\hline United Kingdom & 0.8 & 0.2 & 0.2 & 0.2 & 0.2 & 0.2 & 0.2 & 0.2 & 0.3 & 32.1 & 0.7 \\
\hline United States & 0.5 & 0.3 & 0.2 & 0.1 & 0.1 & 0.2 & 0.1 & 0.1 & 0.3 & 25.9 & 0.5 \\
\hline OECD - average & 0.6 & 0.3 & 0.4 & 0.3 & 0.3 & 0.4 & 0.3 & N/A & 0.4 & 34.4 & 0.01 \\
\hline South Africa & & 0.1 & 0.0 & 0.0 & 0.0 & 0.0 & 0.0 & 0.0 & 0.1 & 27.8 & 0.2 \\
\hline
\end{tabular}

$\mathrm{OECD}$, Organisation for Economic Co-operation and Development; N/A, not applicable; GDP, gross domestic product.

The highest wealth tax yield is in Switzerland with an average of $1.0 \%$ of GDP over the 41 -year period and $1.4 \%$ of GDP in 2015. Most of Switzerland's wealth tax is derived by way of recurrent wealth tax levied from individuals. The wealth tax yield of other countries lags quite far behind Switzerland. France is in second place, with an average of $0.4 \%$ of GDP over the 41 -year period and $0.8 \%$ of GDP for 2015. France derives most of its wealth tax by way of estate, inheritance and gift taxes as explained above. Part of France's growth in wealth tax contributions is the result of recurrent wealth tax, but the main reason for the growth is the increase in contributions from the inheritance tax. Belgium is in third place, with an average of $0.6 \%$ of GDP over the 41 -year period and $0.7 \%$ of GDP for 2015 .

Some other OECD countries have experienced an increase in wealth tax contributions over the period, but for the most part these increases have not been significant. The data in
Table 2 indicate that 13 countries have seen a decline in the wealth tax contributions from 1965 to 2015, 5 have seen a decline from 2014 to 2015 and 10 have seen a decline from 2013 to 2015.

South Africa's wealth tax collections averaged $0.1 \%$ of GDP, which is lower than the OECD average of $0.4 \%$; however, this should be seen in the context of South Africa being a developing country and its tax revenue as a percentage of GDP being lower than the OECD average.

Wealth tax collections over the last 41 years are generally very low across the OECD countries (OECD 2015). Very few countries have managed to increase wealth tax revenue yields in recent years and little international evidence exists to support the notion that wealth tax would be a viable source of additional tax revenues for South Africa, particularly, if the costs of administration and collection are considered. 


\section{Conclusion and recommendations}

The wealth tax experiences over the last few decades in the various countries examined above suggest that for most countries, the levy of wealth tax is implemented as a crisis measure to generate additional revenue in the face of an economic setback and has usually had a short lifespan. France is the only country among the 40 OECD and BRICS countries that has used a recurrent wealth tax on a sustained basis as a fundamental part of its economic policy (Ristea \& Trandafir 2010). The example of France should be distinguished from South Africa, however, as France is a large, developed economy, whereas South Africa is a small, emerging economy and does not have similar economic policies to France.

As indicated by the OECD statistics discussed above, wealth tax collections hover below $1 \%$ of GDP and if viewed in isolation, ignoring any other macroeconomic or political factors, this tax could arguably be replaced with other types of tax or by increasing other tax rates, for example, by increasing normal tax rates on individuals or the value-added tax rate.

No country other than France, Italy and Switzerland has both estate duty or inheritance tax and a recurrent wealth tax. Furthermore, none of the countries considered in this article have both estate or inheritance tax and capital gains tax on the assets of an estate. There is therefore no precedent elsewhere for a policy change that adds a new wealth tax to the estate duty and donations that already exist in South Africa.

Both Canada and Australia have deemed disposals on death like the capital gains tax deemed disposal rule in South Africa, but neither of those countries has estate or inheritance tax. South Africa is the only country that taxes the estate of a deceased person as well as the deemed disposal of that person's assets on death (Ernst and Young 2015:14).

South Africa's estate duty and donations tax systems compare favourably with similar systems used in several other countries internationally in terms of the rates and exemptions that apply. Taxing wealth transfers upon death is possibly the most efficient form of wealth tax as it has less impact on economic decisions than other forms of wealth tax, although the real achievement of this efficiency will depend on the use to which the tax revenue is put. If there was any meaningful yield and the tax was spent appropriately, it could go some way towards addressing economic inequality and thus provide a viable solution to the problem of wealth inequality; however, in view of the low yields experienced internationally, it is very unlikely that there would be sufficient tax revenue to have any impact.

When considering the imposition of a wealth tax, South Africa must evaluate the underlying motivation for such a tax. If the objective is to generate additional tax revenue, the likely net tax yield after implementation and administration costs must be considered. Bird (1991) warns that administrative constraints have usually made these taxes both unproductive and inequitable in developing countries ... their most sophisticated version - the net wealth tax - has proved a costly mistake in developing countries that have attempted to implement it. (p. 323)

Even among the OECD countries, the yield from wealth tax is very low. There is little evidence to suggest that South Africa, with its small base of taxpayers and very few taxpayers with substantial wealth, would be able to generate meaningful revenue from a wealth tax. If the underlying objective is to use wealth tax to correct the economic imbalance that exists, policymakers would need to be cautious in terms of the expectations, as there is very little evidence to support the argument that wealth tax will bring in a reduction in wealth inequality. The fact that wealth inequality has increased across all developing countries, including countries such as France which has had many years' experience with wealth tax, reinforces the observation made by Ristea and Trandafir that (2010:305) 'wealth tax is not as equitable as it appears'.

Overall, considering the experience of wealth tax in other countries and the present economic climate in South Africa, with very low growth rates and little indication of any significant improvement in the near future (Republic of South Africa, National Treasury 2017), it would seem prudent and appropriate not to introduce a new wealth tax owing to the risk of causing damage to the already vulnerable economy. As the estate duty and donations tax systems are well-established and comparable with other tax systems internationally, indications are that these tax systems should rather be developed and refined to be more efficient and productive. Most importantly, there is no evidence to support the argument that wealth tax could make a meaningful contribution to addressing the existing economic inequality. Serious consideration should rather be given to focusing on measures that will stimulate the economy. This inherently requires that capital should be concentrated where it can be most effectively managed, which is mainly in the hands of entrepreneurs and investors. Transferring additional capital to the government through a wealth tax is unlikely to yield equivalent returns and history has shown that placing more capital in the hands of government does not boost economic growth. Based on the results of this study, it is suggested that the introduction of a new wealth tax may not be a viable option for South Africa at the present time.

\section{Acknowledgements Competing interests}

The authors declare that they have no financial or personal relationships which may have inappropriately influenced them in writing this article.

\section{Authors' contributions}

J.A. was the primary researcher and author and L.S. supervised the research project. 


\section{References}

Bach, S., Beznoska, M. \& Steiner, V., 2014, 'A wealth tax on the rich to bring down public debt? Revenue and distributional effects of a capital levy in Germany' Fiscal Studies 35(1), 67-89. https://doi.org/10.1111/j.1475-5890.2014.12023.x

Bird, R.M., 1991, 'The taxation of personal wealth in international perspective', Canadian Public Policy 17(3), 322-334. https://doi.org/10.2307/3551639

Boadway, R., Chamberlain, E. \& Emmerson, C., 2010, Taxation of wealth and wealth transfers, Mirrlees Review, London.

Chatalova, N. \& Evans, C., 2013, 'Too rich to rein in? The under-utilised wealth tax base', E Journal of Tax Research 11(3), 434-452.

Chibber, K., 2014, 'A short history of France's battles over taxing the wealthy', Quartz a Work, 12 October, viewed 06 December 2016, from http://qz.com/279900/ a-short-history-of-frances-battles-over-taxing-the-wealthy

Cole, A., 2015, Estate and inheritance taxes around the world, Tax Foundation, viewed 16 January 2017, from http://taxfoundation.org/article/estateandinheritancetaxe saroundworld

Connexion, 2010, French wealth tax explained in full, connexionfrance.com, viewed 06 January 2017, from http://www.connexionfrance.com/wealth-tax-franceexplained-impot-de-solidarite-sur-la-fortune-isf-10573-news-article.html

Credit Suisse, 2014, Global wealth report, Credit Suisse, Zurich viewed 21 October 2017 from https://publications.credit-suisse.com/tasks/render/file/?fileID=60931FDEA2D2-F568-B041B58C5EA591A4

Daniel, P., De Mooij, R., Matheson, T. \& Michielse, G., 2011, Iceland: Advancing tax reform and the taxation of natural resources, International Monetary Fund Washington, DC

Davies, J.H., 1984, 'Income-plus-wealth: In search of a better tax base', Rutgers Law Journal 15(4), 849-896.

Davis Tax Committee, 2013, Terms of reference, TaxCom, viewed 15 October 2014 from http://www.taxcom.org.za/termsofreference.htm

Davis Tax Committee, 2016, Second interim report on estate duty, viewed 28 Augus 2016, from http://www.taxcom.org.za/docs/20160428\%20DTC\%20Final\%20 Report\%20on\%20Estate\%20Duty\%20-\%20website.pdf

Denk, O., 2012, Tax reform in Norway: A focus on capital Taxation, OECD Publishing, Paris.

Duff, D.G., 1993, 'Taxing inherited wealth: A philosophical argument', The Canadian Journal of Law and Jurisprudence 6(1), 3-62. https://doi.org/10.1017/S0841820 Journal of Law

Duff, D.G., 2005, Abolition of wealth transfer taxes: Lessons from Canada, Australia and New Zealand, bepress Legal Series, University of Toronto, Toronto, Canada, viewed 21 February 2017, from http://law.bepress.com/expresso/eps/611

Ernst and Young, 2015, Wealth under the spotlight 2015: How taxing the wealthy is changing, 6th edn., viewed 17 February 2017, from ey.com: http://www.ey.com/ Publication/vwLUAssets/EY-wealth-under-the-spotlight-2015/\$FILE/EY-wealthunder-the-spotlight-2015.pdf: EYGM Limited

Ernst and Young, 2016a, Worldwide estate and inheritance guide 2016, Retrieved from EYGM Limited, viewed 16 January 2017, from http://www.ey.com/Publication/ vwLUAssets/ey-worldwide-estate-and-inheritance-tax-guide-june-2016/\$FILE/ ey-worldwide-estate-and-inheritance-tax-guide-june-2016.pdf

Ernst and Young, 2016b, Worldwide personal tax and immigration guide, viewed 16 January, from ey.com: http://www.ey.com/Publication/vwLUAssets/Worldwide Personal Tax and Immigration Guide 2016-17/\$FILE/Worldwide\%20Personal\%20 Tax\%20añ $\% \overline{2}$ OImmigration\%20Guide\%202016-17.pdf

Escolano, J., Matheson, T., Heady, C. \& Michielse, G., 2010, Iceland: Improving the equity and revenue production of the icelandic tax system, International Monetary Fund, Washington, DC

Evans, C., 2013, Wealth taxes: Problems and practice around the world, Birmingham University, viewed 15 October 2014, fromwww.birmingham.ac.uk

Gissurarson, H. \& Mitchell, D., 2007, 'The Iceland tax system', Centre for Freedom and Prosperity 7, 1-19.

Government of India Ministry of Finance, 2015, Memorandum explaining the provisions in the Finance Bill, 2015, viewed 25 September 2017, from http:// indiabudget.nic.in/ub2015-16/memo/mem1.pdf

Huang, C. \& Cho, C., 2016, Ten facts you should know about the federal estate tax, Center on Budget and Policy Priorities, Washington, DC.

Jooste, R., 2014, Budget: Personal taxes, Financial Mail, viewed 15 October 2014, from http://www.financialmail.co.za/specialreports/budget2014/2014/02/27/budgetpersonal-taxes
KPMG, 2016, Iceland - Other taxes and levies, viewed 16 December 2016, from kpmg. com: https://home.kpmg.com/xx/en/home/insights/2011/12/iceland-other-taxeslevies.html

Lamprecht, I., 2014, Tax committee to probe VAT, mining tax and wealth tax Moneyweb, viewed 17 February 2017, from http://www.moneyweb.co.za/ moneyweb-2014-budget/tax-committee-to-probe-vat-mining-and-wealth-tax

Landman, J.P., 2014, Breaking the grip of poverty and inequality in South Africa 2004 2014: Current trends, issues and future policy options, Southern African Regional Poverty Network, viewed 17 January 2017, from http://www.sarpn.org/documents/ d0000649/P661-Povertyreport3b.pdf

McDonnell, T.A., 2013, Wealth tax: Options for its implementation in the Republic of Ireland, Northern Ireland: NERI Working Paper Series No. 6, TASC, Belfast.

New Statesman, 2012, What can Iceland teach us about a wealth tax?, newstatesman. com, viewed 06 December 2016, from http://www.newstatesman.com/print/ node/129491

Organisation for Economic Co-operation and Development (OECD), 2015, Revenue statistics: Comparative tables, OECD.org, viewed 16 February 2017, from http:// dx.doi.org/10.1787/6e3323fd-en

Organisation for Economic Cooperation and Development (OECD), 2017, Income distribution and poverty, viewed 22 February 2017, from oecd.com: http://stats. oecd.org/Index.aspx?DataSetCode=IDD

Rakowski, E., 1999, 'Can wealth taxes be justified?', Tax Law Review 53, 263-281.

Republic of South Africa, 2013, Budget speech, National Treasury, viewed 17 February 2017, from http://www.treasury.gov.za/documents/national\%20budget/2013/ speech/speech.pd

Republic of South Africa, 2014, Medium term budget policy statement speech National Treasury, viewed 17 February 2017, from http://www.treasury.gov.za/ documents/mtbps/2014/mtbps/speech.pdf

Republic of South Africa, 2016, Budget speech, National Treasury, viewed 17 February 2017, from http://www.treasury.gov.za/documents/national\%20budget/2016/ speech/speech.pdf

Republic of South Africa, National Treasury, 2017, Budget review, Government Printer Pretoria, viewed 21 October 2017, from http://www.treasury.gov.za/documents/ national\%20budget/2017/review/FullBR.pdf

Ristea, L. \& Trandafir, A., 2010, 'Wealth tax within Europe in the context of a possible implementation in Romania - The existing wealth tax and its decline in Europe', Annals of the University of Petroşani, Economics 10(2), 299-306.

Rudnick, R.S. \& Gordon, R.K., 1996, 'Taxation of wealth'. in V. Thuronyi (ed.), Tax law design and drafting, p. Chapter 10, International Monetary Fund, Washington, DC, pp. 1-46.

Schnellenbach, J., 2012, 'The economics of taxing net wealth: A survey of the issues', Public Finance \& Management 12(4), 368-400.

Shakow, D. \& Shuldiner, R., 2000, 'A comprehensive wealth tax', University of Pennsylvania Law School, Faculty Scholarship, Paper 1264, 499-585.

Singh, S., 2015, 'Wealth tax abolished, 2\% surcharge on super rich', The Indian Express, 01 March, viewed 26 September 2017, from http://indianexpress.com/article/ business/budget/wealth-tax-abolished-2-surcharge-on-super-rich/

South African Revenue Service, 2016, Tax statistics, SARS, Pretoria, viewed 29 September 2017, from http://www.sars.gov.za/About/SATaxSystem/Pages/Tax-Statistics.aspx

Sowetan, 2013, Motsepe family to give away big slice of fortune, Sowetan, viewed 16 October 2014, from http://www.sowetanlive.co.za/news/2013/01/30/motsepefamily-to-give-away-big-slice-of-fortune

Teuchert, M., 2014, Wealth tax will drive the rich out of South Africa, Fin24, viewed 15 October 2014, from http://www.fin24.com/Budget/Implications-of-a-wealthtax-20140221

Veritas Wealth Management, 2014, The Davis Tax Committee: Financial friend or foe? Veritaswealth, viewed 15 October 2014, from http://veritaswealth.co.za/thedavis-tax-committee-financial-friend-or-foe $/ \mathrm{htm}$

Williams, M., 2011, Tutu calls for a wealth tax on whites, IOL News, viewed 15 October 2014, from http://www.iol.co.za/news/politics/tutu-calls-for-wealth-tax-on-whites1.1116744\#.VD6C110cTDc

World Bank, 2014, World development indicators, The World Bank Group, viewed 20 October 2017, from http://data.worldbank.org/data-catalog/world-developmentindicators

Ydstedt, A., 2016, How high-tax Sweden abolished its disastrous inheritance tax Institute of Economic Affairs, viewed 17 February 2017, from https://iea.org.uk/ blog/how-high-tax-sweden-abolished-its-disastrous-inheritance-tax

Zerbst, F., 2013, 'Is it time to tax the wealthy?', FA News, 25 February, viewed 15 October 2014, from http://www.fanews.co.za/article/tax/16/tax/1016/is-it-timeto-tax-the-wealthy/13195 